\title{
Diarrhetic shellfish toxicity in relation to the abundance of Dinophysis spp. in the German Bight near Helgoland
}

\author{
Sascha Klöpper ${ }^{1,2, *}$, Renate Scharek ${ }^{1,3}$, Gunnar Gerdts ${ }^{1}$ \\ ${ }^{1}$ Biologische Anstalt Helgoland (BAH, AWI), Kurpromenade, 27498 Helgoland, Germany \\ ${ }^{2}$ Present address: Center for Tropical Marine Ecology (ZMT), Fahrenheitstrasse 6, 28359 Bremen, Germany \\ ${ }^{3}$ Present address: Institut de Ciencies del Mar (ICM, CSIC), Passeig Marítim de la Barceloneta, 37-49, 08003 Barcelona, Spain
}

\begin{abstract}
Diarrhetic shellfish toxicity is caused by the accumulation of okadaic acid and its derivatives, which are produced by particular species of Dinophysis Ehrenberg 1839 and Prorocentrum Ehrenberg 1833 (Dinoflagellata). In the German Bight (North Sea) around the island of Helgoland, 4 toxic Dinophysis species occur, of which 2 exhibited successive biomass maxima in summer 2000 (D. norvegica Claparède et Lachmann 1859 with cell concentrations of max. 400 cell $l^{-1}$ and $D$. acumi-

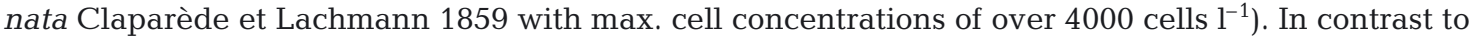
findings in other marine areas, toxicity of Mytilus edulis Linné 1758 could be clearly attributed to the observed increases in cell abundances of both species. In several Mytilus samples toxin concentrations (max. $460 \mathrm{ng}$ diarrhetic shellfish poisoning [DSP] toxins $\mathrm{g}^{-1}$ hepatopancreas) were in a range which is considered dangerous for human consumption. While mussel toxicity coincided with concentration increases of both Dinophysis species, toxicity of the particulate substance in the water (max. $26 \mathrm{ng} \mathrm{l}^{-1}$ ) could be detected only during cell concentration maxima of $D$. acuminata. Mussel toxicity lasted $3 \mathrm{wk}$ after the end of the $D$. acuminata bloom, and this is attributed to extended toxicity of decaying Dinophysis cells and detritus. Elevated summer temperatures and low silicate concentrations evidently supported the development of high concentrations of $D$. acuminata.
\end{abstract}

KEY WORDS: Toxic dinoflagellates · Diarrhetic shellfish poisoning $\cdot$ DSP $\cdot$ Harmful algal blooms · HAB $\cdot$ Phytoplankton

\section{INTRODUCTION}

In the German Bight of the North Sea, around the island of Helgoland, dinoflagellates of the genus Dinophysis Ehrenberg regularly occur during summer. Long-term observations from the Helgoland Reede time-series indicate that highest cell concentrations arise in summer or late summer (Hickel et al. 1997, E. Hagmeier unpubl.). In various European coastal regions (e.g. Norway, Denmark and Sweden), Dinophysis spp. are suspected of being responsible for diarrhetic shellfish poisoning (DSP) (Séchet et al. 1990, Anderson et al. 1996, Lindahl \& Anderson 1996). DSP results from a widely distributed type of contamination of edible bivalves like mussels, which feed by filtering particles from seawater. These particles, which accumulate in the digestive glands and stomach (hepatopancreas), may potentially contain toxic phytoplankton cells like Dinophysis spp. In cases of high cell abundances of these toxic species, the consumption of only 1 mussel may be enough to cause toxic effects in humans. Although the first detailed report of DSP dates from 1978 in Japanese waters (Yasumoto et al. 1978), gastrointestinal poisoning of humans after consumption of mussels had been observed about $20 \mathrm{yr}$ earlier in northern Europe (Krogh et al. 1985).

The toxins which cause DSP are the polyether molecules okadaic acid (OA), its derivatives dinophysistoxin- 
1, -2 and -3 (DTX), 7-acetyl okadaic acid, okadaic ethyl ester, as well as yessotoxin and pectenotoxins (Yasumoto et al. 1989). The gastrointestinal symptoms of DSP, which causes extreme liquid loss, begin within 30 min to a few hours after consumption of toxic shellfish and consist of abdominal pain and cramps, incapacitating diarrhea, nausea, vomiting and chills (Tubaro et al. 1996). The ailment clears up within 3 d with or without medical treatment (Hallegraeff 1993). Fatal incidents based on DSP have not been recorded, but the DSP toxins may have the potential to induce tumors in the gastrointestinal tract (Suganuma et al. 1988).

Findings about correlations between Dinophysis cell concentrations and DSP toxicity of mussels have been controversial. For example, investigations in French coastal waters revealed no clear relationship between shellfish toxicity and Dinophysis spp. occurrence (Lassus et al. 1991). Similar observations were made in a Norwegian bay: no apparent relation between Dinophysis spp. concentrations and mussel toxicity was observed (Dahl \& Johannessen 2001). On the other hand, in a Norwegian fjord DSP-toxin concentrations in blue mussels followed changes in Dinophysis spp. cell densities (Séchet et al. 1990).

We carried out our investigations in spring and summer 2000 in order to search for a relationship between Dinophysis spp. cell densities and mussel toxicity in the German Bight near the island of Helgoland. inverse microscope (Zeiss Axiovert 135) was equipped with light, phase contrast and differential interference contrast objectives and with a video imaging system. Additionally, samples were taken by net $(20 \mu \mathrm{m}$ mesh size) for qualitative analysis and documentation. Samples were stored in $200 \mathrm{ml}$ bottles with a higher concentration of fixative ( $2 \%$ final concentration).

To determine the DSP-toxin content of the particulate substance in the water, 3 samples of a larger amount of seawater (up to 15 l) were taken by sampling bottle from the surface, parallel to the phytoplankton sample. Up to 51 of water were vacuum filtered on GF/C filters (47 mm diameter, nominal pore size $1.2 \mu \mathrm{m}$ ), and were stored at $-20^{\circ} \mathrm{C}$ until measurement.

Specimens of Mytilus edulis were collected at least once a week in an intertidal rocky area at the northeastern part of the island. The number of mussels varied from 5 to 16, depending on their size. In the laboratory the mussels were steamed for $2 \mathrm{~min}$ and the hepatopancreas (stomach and digestive glands) was separated and analyzed immediately or stored in 3 aliquots of at least $1 \mathrm{~g}$ wet weight at $-80^{\circ} \mathrm{C}$ until analysis. Due to the varying size of the collected mussels, 1 to 5 specimens were required per analysis.

Salinity and temperature data were obtained from the Helgoland Reede time-series (Hickel et al. 1997).

Determination of DSP toxins. Toxins from particulate substance and mussels were extracted according to Tubaro et al. (1996), with some modifications. The thawed GF/C filters with the particulate substance

\section{MATERIALS AND METHODS}

We investigated which Dinophysis species were potentially involved in causing DSP effects by monitoring their cell concentrations. Furthermore, we measured DSP toxins in mussels and in the particulate substance of the water column.

Investigation area and sampling. The investigations were carried out near the island of Helgoland in the German Bight (North Sea) from April to October 2000. Phytoplankton samples (1 l) were taken daily by means of sampling bottles from the surface parallel to the sampling of the Helgoland Reede time-series at the position 'Kabeltonne', which is located between the island and the dune $\left(54^{\circ} 11.3^{\prime} \mathrm{N}, 7^{\circ} 54^{\prime} \mathrm{E}\right.$; Fig. 1; Hickel et al. 1997). An aliquot of $100 \mathrm{ml}$ seawater was fixed with a hexamin buffered $20 \%$ formaldehyde solution (final concentration $0.5 \%$ ). Dinophysis spp. cells and other potentially harmful phytoplankton species were identified and counted according to the method described by Utermöhl (1958). The

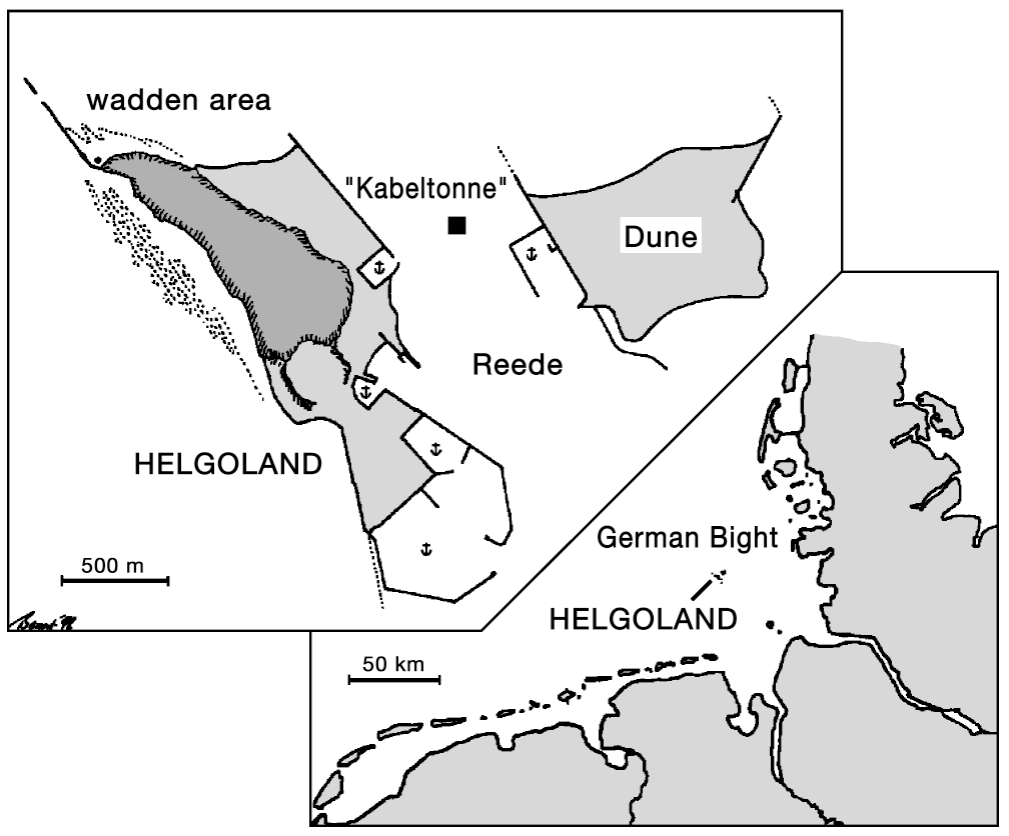

Fig. 1. Location of Helgoland in the German Bight (North Sea), showing the sampling sites 'Kabeltonne' (Helgoland Reede time-series) and the intertidal rocky area 
samples were homogenized in $1 \mathrm{ml}$ liquid $(50 \%$ methanol, 50\% Milli-Q) by ultrasound (1 $\mathrm{min}, 60 \mathrm{~W}$ ). Subsequently, the liquid was taken up by a syringe and centrifuged $(10 \mathrm{~min}, 16000 \times g)$. The supernatant was evaporated and the dry matter was once more extracted in $100 \mu \mathrm{l}$ methanol. If not immediately used, the liquid samples were stored at $-20^{\circ} \mathrm{C}$.

Samples of Mytilus edulis hepatopancreas were homogenized for $1 \mathrm{~min}$ by Ultra-Thurrax in liquid (50\% methanol, $50 \%$ Milli-Q). After centrifugation $(10 \mathrm{~min}, 1993 \times \mathrm{g})$ and addition of $10 \mathrm{ml}$ Milli-Q, to lower the methanol portion, the supernatant was liquid-extracted twice with an equal quantity of ethyl acetate $(10 \mathrm{ml})$. A formation of a third phase, which seemed to be a fatty emulsion, was observed in several samples. Sodium chloride $(3 \mathrm{~g})$ was added to support the division of the phases. The pooled organic phases were dried on $3 \mathrm{~g}$ sodium sulfate. After removing the liquid with a vacuum concentrator, the dry matter was dissolved in $100 \mu \mathrm{l}$ methanol. The samples were stored at $-20^{\circ} \mathrm{C}$ until measurement.

The DSP-toxin contents of the particulate substance and hepatopancreas of Mytilus edulis were assessed with a protein phosphatase Type 2A (PP2A) inhibition assay, described by Tubaro et al. (1996), applied with a few modifications. In this assay, DSP toxins are measured as OA equivalents. The amount of enzyme added ( 0.01 or $0.02 \mathrm{U}$ of protein phosphatase Type $2 \mathrm{~A}$, isolated from human blood cells, Biomol) differed because of the varying activity of the charges used. For the analyses, multiplate wells were used. Each well contained $20 \mu$ l enzyme substrate (Sigma $104^{\circledR}$ P-nitrophenyl-phosphate, P-NPP, $0.282 \mathrm{M}), 1 \mu \mathrm{l}$ sample, and 1 or $2 \mu$ PP2A-dilution. It was filled with buffer $(40 \mathrm{mM}$ Tris/ $/ \mathrm{HCl} 34 \mathrm{mM} \mathrm{MgCl}_{2}, 4 \mathrm{mM}$ EDTA, $4 \mathrm{mM}$ DLdithioreithol, $\mathrm{pH}$ 8.4) to a volume of $200 \mu$ l. Measurements were carried out in a spectrophotometer (Anthos luminometer lucy 1 16800) at $405 \mathrm{~nm}$ wavelength. In order to inhibit the enzymatic activity before starting the measurement, the multiplate well was stored on ice. Nine OA concentrations, with 2 parallel batches in each set-up, ranging from 0 to $5 \mu \mathrm{g} \mathrm{ml}^{-1}$ diluted in methanol, were prepared from a stock solution $(5 \mu \mathrm{g}$ $\mathrm{ml}^{-1}$, from Prorocentrum concavum isolates, Sigma). One concentration series was measured on each plate to obtain a calibration curve.

\section{RESULTS}

\section{Dinophysis spp. near the island of Helgoland}

Four Dinophysis species were observed off Helgoland during summer 2000. The highest cell concentrations of Dinophysis spp. were recorded from mid-
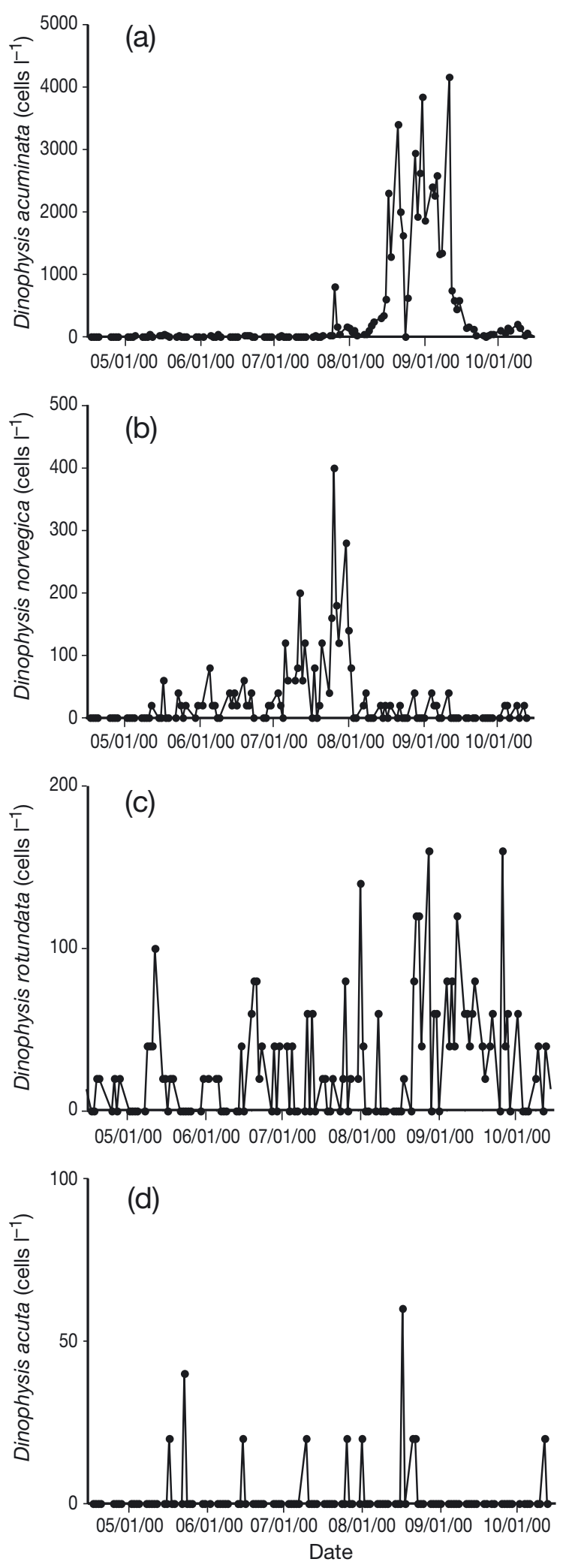

Fig. 2. Dinophysis spp. Concentrations measured during the investigation period (April 15 to October 15, 2000): (a) $D$. acuminata; (b) D. norvegica; (c) D. rotundata; and (d) D. acuta. Dates given as mm/dd/yy 

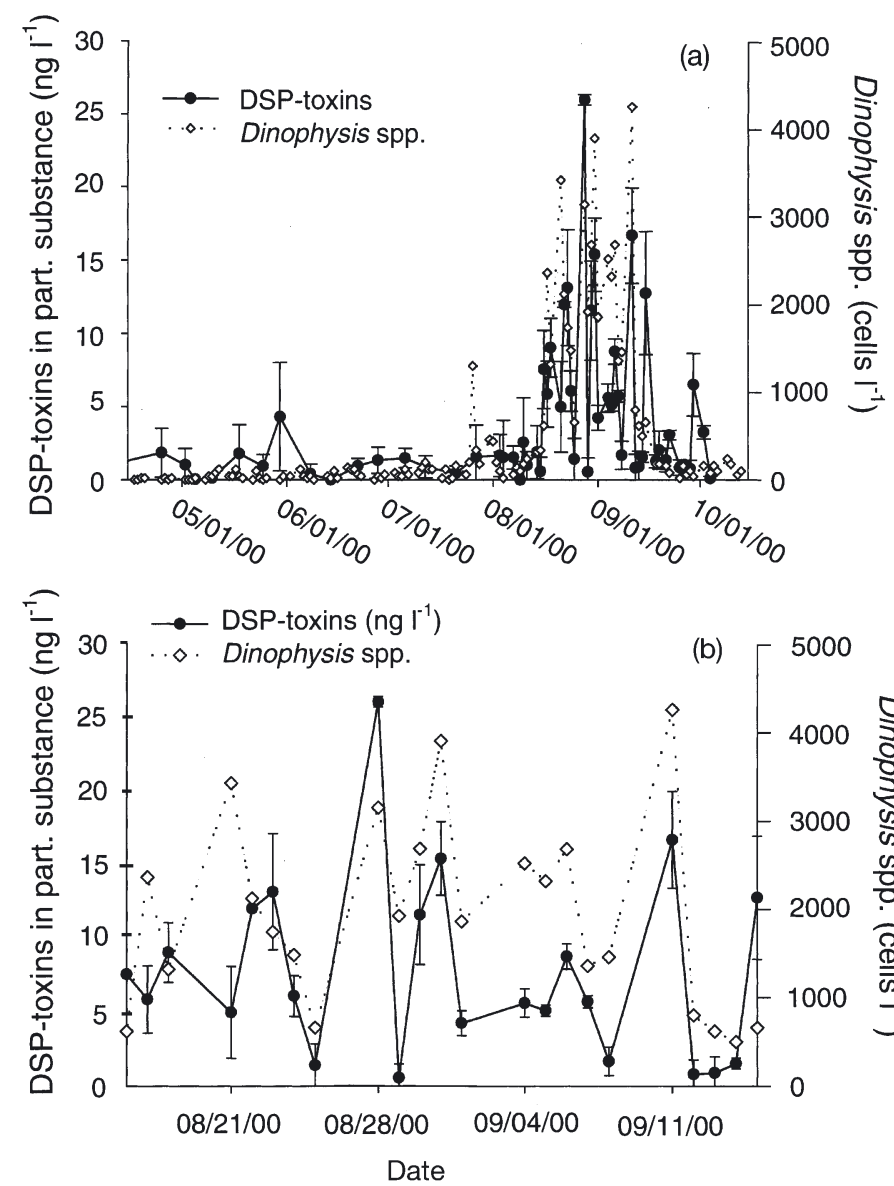

Fig. 3. Concentrations of diarrhetic shellfish poisoning (DSP) toxins in the particulate substance of the water column. Also indicated are concentrations of Dinophysis spp.: (a) during entire investigation period (mid-April until mid-October 2000); (b) from mid-August until mid-September. Dates given as $\mathrm{mm} / \mathrm{dd} / \mathrm{yy}$

August to mid-September. The most abundant species was D. acuminata Claparède et Lachmann 1859, with a

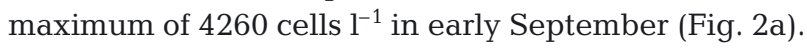
Cell concentrations of $D$. norvegica Claparède et Lachmann 1859, which was the second most abundant Dinophysis species, increased during July to concentrations of 400 cells $\mathrm{l}^{-1}$, about a tenth of maximum $D$. acuminata cell abundances (Fig. 2b). D. rotundata Claparède et Lachmann 1859 and D. acuta Ehrenberg 1841 (in order of detected cell maxima) played a minor role, and concentrations $>160$ cells $1^{-1}$ were never recorded (Fig. 2c,d).

\section{DSP-toxin concentrations in particulate substance of the water column and in mussel hepatopancreas}

The increase in DSP toxins in the particulate substance of the water column coincided with the peak of Dinophysis spp. between mid-August and midSeptember (mainly caused by Dinophysis acuminata, Fig. 3a). During this period, toxin concentrations increased ca. 5-fold and more from previous values of ca. $2 \mathrm{ng} \mathrm{l}^{-1}$. Meanwhile, Dinophysis cell concentrations varied between 1000 and 4000 cells $1^{-1}$.

During the interval of highest Dinophysis cell concentrations (mid-August to mid-September) the slope of the linear regression of cell concentrations against particulate substance toxin concentrations indicates an average toxin content of $3.3 \mathrm{pg} \mathrm{cell}^{-1}$ (DSP toxins measured as OA equivalents; Fig. 4). Interestingly, the toxin content in the water column stayed rather high until the beginning of October (Fig. 3a). At the beginning of this period, the oscillations of cell concentrations and DSP-toxin concentrations in the particulate substance took opposite courses. On days with higher concentrations of Dinophysis spp., less particulate substance toxicity was measured and vice versa. After approximately $1 \mathrm{wk}$, the situation changed and the development of cell and DSP toxin concentrations ran parallel (Fig. 3b).

The first noticeable rise in DSP-toxin content in mussel hepatopancreas tissue (HP) was measured on 14 June. Concentrations ranged between 140 and $190 \mathrm{ng} \mathrm{g}^{-1} \mathrm{HP}$ until the third week of August (Fig. 5). The described increase in Dinophysis norvegica took place in the middle of this period, during July. From the 4th week of August the toxicity of the mussels increased to concentrations over $400 \mathrm{ng} \mathrm{g}^{-1} \mathrm{HP}$. The concentrations of OA and its derivatives in the HP fluctuated from then on, yet remained at a high level for 6 wk until the beginning of October (Fig. 5). High densities of $D$. acuminata were detected only until midSeptember. During the period of very high HP DSPtoxin contents, some samples contained concentrations

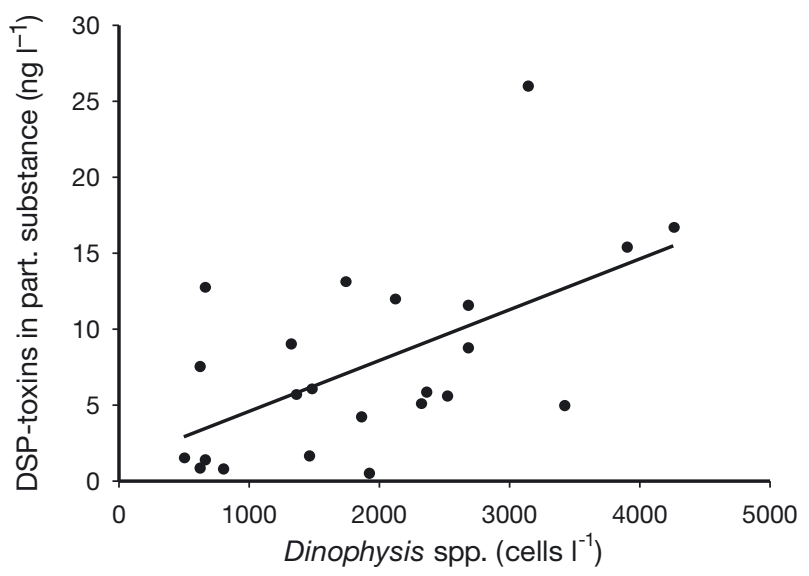

Fig. 4. Dinophysis spp. Linear regression of cell concentrations against particulate substance toxin concentrations during the period from mid-August until mid-September $\left(y=0.0033 x+1.3224 ; \mathrm{r}^{2}=0.33 ; \mathrm{p}<0.005\right)$. Dates given as $\mathrm{mm} / \mathrm{dd} / \mathrm{yy}$ 


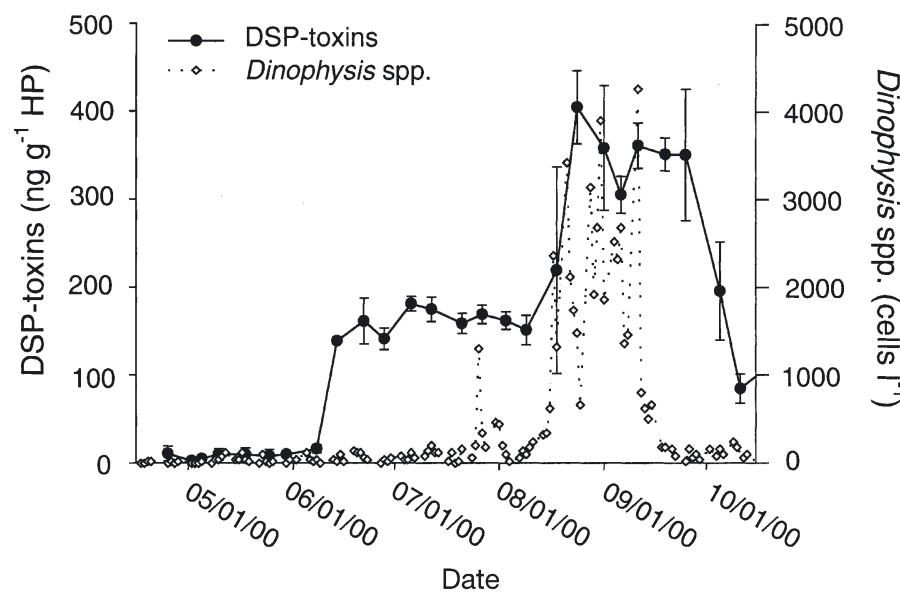

Fig. 5. Concentrations of okadaic acid and its derivatives (DSP toxins) in mussel hepatopancreas tissue (HP) during the investigation period (mid-April until mid-October 2000). Indicated as well are concentrations of Dinophysis spp. Dates given as $\mathrm{mm} / \mathrm{dd} / \mathrm{yy}$

which were even above the highest OA concentration of the calibration curves $(5 \mathrm{ng}$ OA in $1 \mu$ calibration liquid).

In the first week of October, mussel toxicity started to decrease, and in the second week values were lower than $100 \mathrm{ng} \mathrm{g}^{-1} \mathrm{HP}$ (Fig. 5).

The protein phosphatase 2A inhibition assay is an indirect method to determine DSP toxicity. Because it measures inhibition of phosphatase activity, the possibility exists that interference by phosphatase inhibitors other than the DSP toxins could occur, which may share the same binding site on the PP2A molecule (Takai et al. 1995). Substances known as inhibitors are microcystin-LR (isolated from fresh and brackish water cyanobacteria), calyculin A (marine sponge; Bagu et al. 1996) and tautomycin (soil bacteria; Serres et al. 2000). We can exclude those substances as the responsible inhibitors of the PP2A used in our assays, because these organisms do not occur in the German Bight of the North Sea. During our investigations some samples were measured by high performance liquid chromatography (HPLC). These measurements corroborated our results. During the increase in Dinophysis cell concentrations and in particulate substance and mussel HP toxicity (measured by PP2A inhibition assay), an increase in DSP toxins was measured as well by HPLC (B. Luckas pers. comm.).

\section{Temperature and salinity}

Salinities fluctuated from about 32 to 34 from midApril until the end of July. During August salinities dropped to below 32 and started to increase again by the end of the month, until the end of the investigation period. The highest temperatures (max. daily value $17.8^{\circ} \mathrm{C}$ ) were also recorded in August. Temperatures started to decrease during the second week of September (Fig. 6).

During our investigation period from mid-April to mid-October, the lowest salinities coincided with the warmest period. The interval of highest cell densities of Dinophysis acuminata occurred during this period.

\section{Nutrients}

Nitrate concentrations were higher than $30 \mu \mathrm{mol} \mathrm{l}^{-1}$ at the beginning of the investigation period and decreased to less than $10 \mu \mathrm{mol} \mathrm{l} \mathrm{l}^{-1}$ at the end of May. In July the concentrations dropped further to less than $5 \mu \mathrm{mol} \mathrm{l} \mathrm{l}^{-1}$. The lowest concentrations of nitrate were measured in August and September; towards the end of September the concentrations increased again (Fig. 7a).

Ammonium concentrations ranged from 0 to $>3 \mu \mathrm{mol} \mathrm{l}{ }^{-1}$, with strong oscillations. Highest concentrations were measured in the period from the end of July until mid-August (Fig. 7a).

Similar to nitrate, the silicate concentrations were

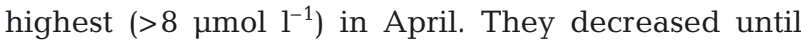
exhaustion in the first half of June but recovered during summer (with another maximum of $>8 \mu \mathrm{mol} \mathrm{l}^{-1}$ in the first half of July). A second drop in concentrations occurred in the second half of August, with a subsequent recovery (Fig. 7b).

In the third week of April, daily phosphate concentrations fluctuated between 0.7 and $1.1 \mu \mathrm{mol} \mathrm{l}^{-1}$. In May, concentrations oscillated between 0 and $0.8 \mu \mathrm{mol} \mathrm{l^{-1 }}$. Afterwards, until the end of June, phos-

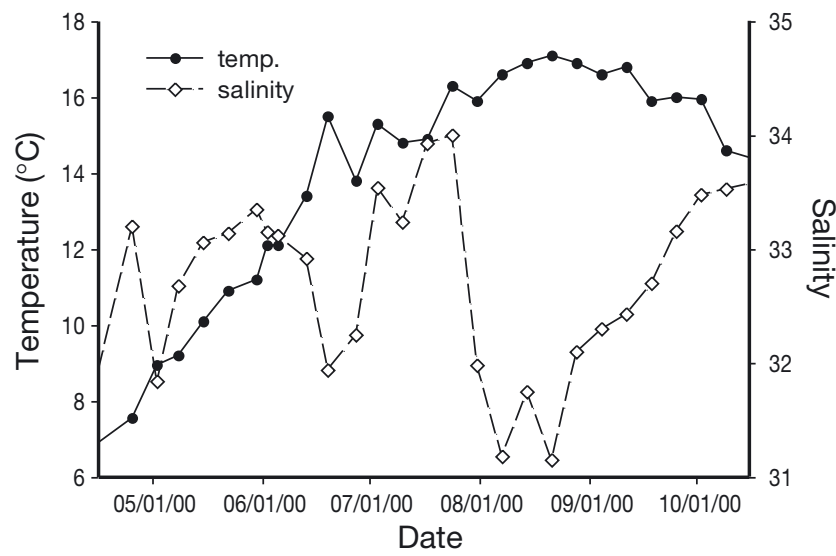

Fig. 6. Weekly medians of temperature and salinity at the sampling site 'Kabeltonne' during the investigation period (April 15 to October 15, 2000). Dates given as mm/dd/yy 

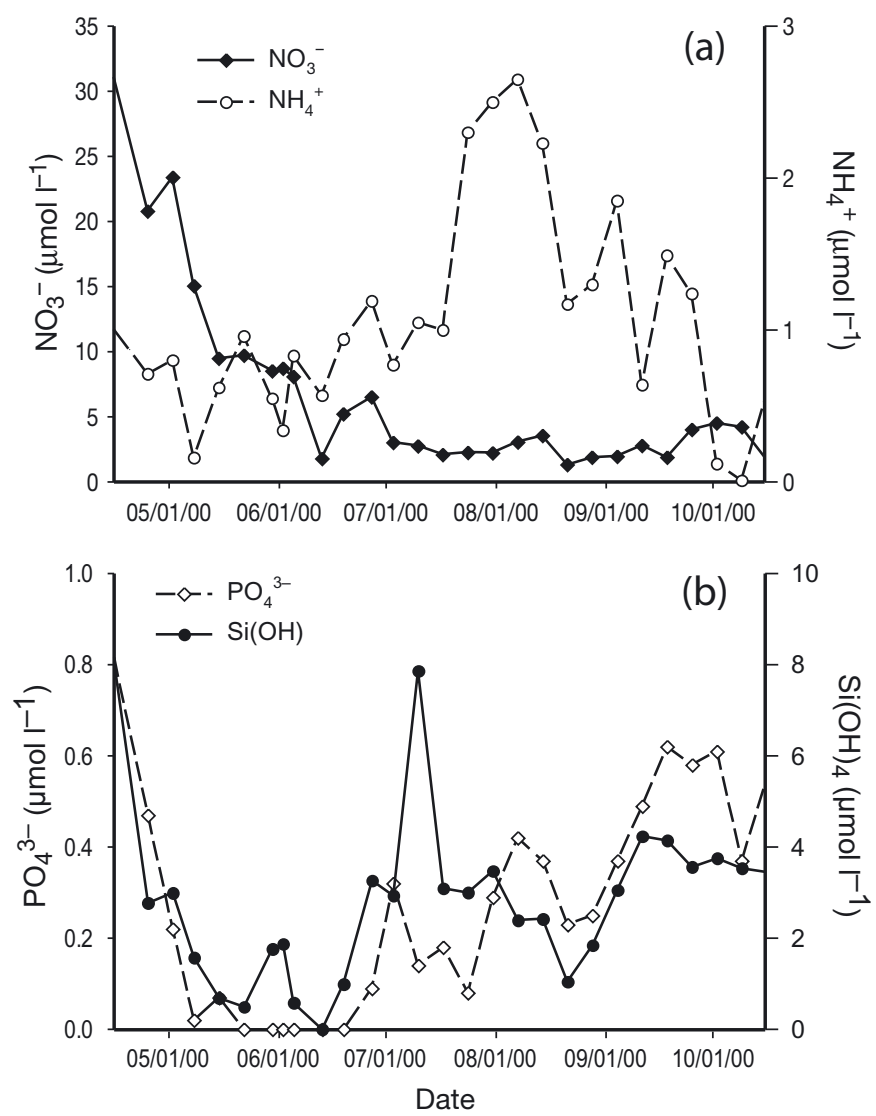

Fig. 7. Weekly median concentrations of inorganic nutrients at the sampling site 'Kabeltonne' during the investigation period (April 15 to October 15, 2000). (a) Concentrations of nitrate and ammonium; (b) concentrations of phosphate and silicate. Dates given as mm/dd/yy

phate was generally not detectable. Concentrations recovered towards July, with strong oscillations (0.2 to $1.1 \mu \mathrm{mol} \mathrm{l}^{-1}$ ) but an overall tendency to increase (Fig. 7b).

\section{DISCUSSION}

\section{Dinophysis abundance and DSP toxicity near Helgoland}

Our investigations demonstrated, for the first time, the presence of DSP toxins in the German Bight near Helgoland. Two Dinophysis species, D. acuminata and $D$. norvegica, appeared to be mainly responsible for DSP toxins in the particulate substance of the water column and hepatopancreas of mussels Mytilus edulis.

The first conspicuous increase in OA and its derivatives in mussels was detected in mid-June 2000, when the total concentration of Dinophysis was around
100 cells $\mathrm{l}^{-1}$. In this period, during which medium to high HP toxin concentrations were found, the only observed increase in concentrations of $D$. norvegica (beginning of July until beginning of August), as well as the first increase in concentrations of $D$. acuminata (end of July until mid-August) occurred. Both species exhibited relatively low concentrations, resulting in an average Dinophysis spp. concentration of ca. 200 cells $\mathrm{I}^{-1}$. In contrast to the distinct increase in toxicity of mussel HP, the samples of the particulate substance of the water column did not reveal any comparable changes in DSP-toxin concentrations. Taking into consideration the DSP-toxin concentration of ca. $3.3 \mathrm{pg}$ cell ${ }^{-1}$ which we estimated for summer, concentrations in the water column would have increased by less than $1 \mathrm{ng} \mathrm{l}^{-1}$, a signal not clearly distinguishable assuming average background concentrations of $1.3 \mathrm{ng} \mathrm{l}^{-1}$ and its variability (Fig. 3). The increase in toxins in the HP can be related to the feeding behavior of mussels, which accumulate particles like phytoplankton cells, and hence their toxins, in their digestive tract. One mussel filters ca. 301 of seawater $\mathrm{d}^{-1}$ (Clausen \& Riisgard 1996) (taking into consideration the tidally induced dry periods in the intertidal rocky area), resulting in an uptake of 6000 cells $\mathrm{d}^{-1}$ at a cell con-

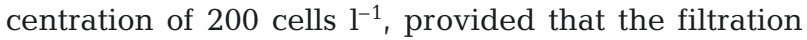
rates are not affected by Dinophysis. Consequently, each mussel took up $19.8 \mathrm{ng}$ DSP-toxin $\mathrm{d}^{-1}$ during that period. Taking into account the average weight of HP per mussel $(0.54 \mathrm{~g})$, the resulting concentration would have been $37 \mathrm{ng}$ DSP toxin $\mathrm{g}^{-1} \mathrm{HP}$. The concentrations measured during this period were ca. 5 times higher. Hence, it appears that the mussels indeed accumulated the toxins in their digestive tract. This estimation, furthermore, is conservative because it is implying a $100 \%$ absorption efficiency. However, there is evidence that Mytilus do not absorb the entire organic material they filter (Hawkins et al. 1998, Cranford \& Hill 1999).

The above estimations were made assuming a direct relationship between the Dinophysis concentrations and HP toxin concentrations measured. The distance between the 2 sites is a little less than $1.5 \mathrm{~km}$ (Fig. 1), which implies that there may be some uncertainty regarding the Dinophysis concentrations present at the mussel sampling site itself. However, we do not expect the Dinophysis concentrations to be very different in the intertidal rocky area because, due to the tidal currents which change their direction nearly twice a day, close interactions between both sites is guaranteed. For logistical reasons, sampling of Dinophysis and the particulate substance always had to be carried out at the same time of day. In order to compensate for variability in Dinophysis and particulate substance concentrations due to variable tidal currents, we carried 
out high frequency sampling (daily). In summary, we conclude that the measured concentrations of both parameters are adequately representative of the concentrations at the mussel sampling site.

\section{Effects of toxic algae on mussels}

Results of investigations on clearance rates of mussels exposed to toxic phytoplankton species vary. The presence of high densities of DSP-producing microalgae might reduce the clearance rates of Mytilus edulis as described by Pilet et al. (1995). Bauder et al. (2001) measured similar clearance rates when scallops Argopecten irradians Lamarck 1819 were exposed to a toxic microalgae diet, in contrast to exposure to nontoxic phytoplankton, but a lower absorption efficiency of organic matter was observed. Sidari et al. (1998) described a feeding preference of blue mussels $M y-$ tilus galloprovincialis Lamarck 1819 for Dinophysis spp., without detecting a correlation between the cell amounts in the digestive glands and the DSP-toxin content. The apparent insensibility of Mytilus spp. to DSP-toxin-producing species appears to have its origin in the apparently harmless effects on the animals themselves. M. galloprovincialis exposed to low cell densities of dinoflagellates Heterocapsa cirqularisquama Horiguchi 1995, which induce mussel mortality by direct cytotoxicity, show significantly reduced clearance rates (Matsuyama et al. 1997).

\section{Delayed detoxification of mussels}

We detected high DSP-toxin levels in the mussel HP up to ca. 3 wk after the period of highest Dinophysis cell concentrations (until the first week of October). The evidently long residence time of DSP toxins in mussels has important implications for the handling of mussels for human consumption. In an area where Dinophysis spp. were apparently DSPtoxin producers, Dahl et al. (1995) lowered mussels to a water depth where concentrations of algae were presumed to be low. They concluded that this technique was not suitable for depuration from toxins because the mussels lost weight and quality due to starvation. A different approach was the transplantation of mussels from a 'toxic' environment to a 'less toxic' environment. An experiment at the Swedish coast showed an average decrease of $12 \mu \mathrm{g}$ OA $100 \mathrm{~g}^{-1}$ mussel meat per day (Haamer et al. 1990b). Depending on the dimensions of a Dinophysis spp. bloom, the possibility of moving a mussel farm could effectively protect against or decontaminate mussels from toxification.

\section{DSP toxins in Dinophysis}

The relatively weak but significant correlation between Dinophysis concentrations and toxin concentrations in the water column during the $D$. acuminata bloom (mid-August until mid-September) might have been caused by variable toxin content in the cells during the bloom process. The dynamics of DSP-toxin production are poorly understood, especially the reasons for the broad range of toxin content per cell and the ratios of OA and its derivatives (Johannson et al. 1996). Ramstad et al. (2001) found that Dinophysis peaks and the concentrations of OA and its derivatives (DTX) in the water column do not always correlate. Provided that Dinophysis spp. are the only producers of DSP toxins in the investigation area, the occurrence of DSP toxins in the particulate substance of the water column until the end of September, 2 wk after cell concentrations of Dinophysis had decreased to prebloom levels, is remarkable. This phenomenon might have been caused by a possible retention of the toxins in dead Dinophysis cells and detritus after the disappearance of Dinophysis. On the other hand, it might be a result of the position of the sampling area and the sampling method, as will be discussed below. An extended presence of DSP toxins in the detritus fraction and decaying Dinophysis would imply a preceding toxin accumulation in mussels by the uptake of particles.

If we apply the decontamination rate measured by Haamer et al. (1990b), the most contaminated mussels we encountered during our investigations (around $400 \mathrm{ng} \mathrm{g}^{-1} \mathrm{HP}$ ) would have been detoxified in ca. half a day. The extended mussel toxicity present $3 \mathrm{wk}$ after the end of the bloom might have been due to the survival of DSP toxins in detritus and decaying Dinophysis. However, in our case it might also have resulted from slower detoxification rates than those measured by Haamer et al. (1990b). It is known, for example, that Mytilus needs several weeks to detoxify paralytic shellfish toxins (Bricelj \& Shumway 1998).

\section{Public health concerns}

The decontamination rate found in this study shows the need to continue monitoring toxin contents of commercial mussels well after Dinophysis concentrations have decreased to background levels. During the Dinophysis acuminata bloom, many mussel HP samples contained DSP-toxin concentrations close to, and some even above, the legal threshold of $450 \mathrm{ng}$ $\mathrm{g}^{-1}$ HP (Bundesministerium für Gesundheit 2000). The respective EU directive (EU 1991) prohibits pro- 
duction or marketing of mussels when test results are positive for DSP toxins in the edible parts. Compared to maximum Dinophysis spp. concentrations of the last $10 \mathrm{yr}$, the maximum cell density during our investigation period was relatively low, since abundances

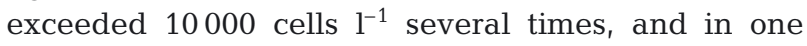
year reached 100000 cells l$^{-1}$ (E. Hagmeier unpubl.). Regarding the observed mussel toxicity in our investigation, the public health risk of DSP is quite obvious. There is evidence that even lower concentrations of Dinophysis spp. can cause higher mussel toxicity than that found in our investigation (Sidari et al. 1998). In comparison to other toxic algae, bloom concentrations of Dinophysis spp. are in general relatively low. Yet Dahl et al. (1996) described one case of a mass occurrence of $D$. norvegica $\left(23 \times 10^{6}\right.$ cells $\left.1^{-1}\right), D$. acuta

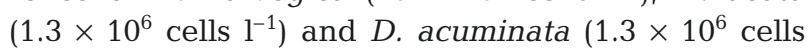
$\mathrm{l}^{-1}$ ) in combination with high cell concentrations of a heterotrophic dinoflagellate (Polykrikos schwartzii

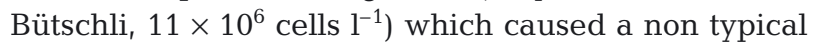
coloration of seawater for Dinophysis spp. blooms.

\section{Why does Dinophysis regularly bloom in summer?}

Research on harmful algal blooms is focussed on the possible prediction of toxic algal events in order to avoid or reduce health and economic damage. Monitoring of physical and chemical parameters can be a tool for this. A decrease in salinities preceded the bloom (from the beginning of August, Figs. 2a \& 6). These findings are in contrast to Haamer et al. (1990a), who found that coastal water with lower salinities appears to counteract the OA contamination of mussels by producing poor conditions for cellular OA synthesis. During the period of decreased salinities, seasonal temperatures were highest, which might be a prerequisite for Dinophysis blooms in that region. Lassus et al. (1991) concluded from their investigations at the French coast that Dinophysis spp. development occurs in relatively warm and low-salinity surface waters. Several authors mentioned a stratified water body as an additional condition (Lassus et al. 1991, Delmas et al. 1992). We assume that stratification occurred around the island of Helgoland from the beginning of August until midSeptember because of calm seas and relatively high surface water temperatures (Fig. 6). We do not have evidence for this, as we did not measure vertical profiles in the water column. However, it is known that summer stratification regularly occurs in the German Bight (Dethlefsen \& Westernhagen 1983, Budéus 1989). On the other hand, our particular sampling position 'Kabeltonne' of the Helgoland Reede timeseries is situated in a relatively narrow channel between the main island and the 'Helgoland Dune' (Fig. 1). Due to tidally induced currents, the body of water is mixed, even when the surrounding water is stratified.

Very contradictory information exists in the literature about the importance of an inorganic nutrient supply for the development of Dinophysis spp. blooms. Delmas et al. (1992) did not detect a relationship between cell concentrations of Dinophysis spp. and the availability of dissolved inorganic nutrients. Another study indicated that increasing nitrate concentrations might stimulate the development of high cell densities (Lassus et al. 1991). Our results provided evidence for a potentially indirect effect of decreased silicate concentrations on the occurrence of Dinophysis spp. Low concentrations of silicate, such as we observed in late spring and in summer, inhibit coastal diatom development (Nelson \& Treguer 1992 and references therein, Kristiansen et al. 2000), which might, in combination with high temperatures, create favorable conditions for dinoflagellates including Dinophysis species. Similar observations were made in Swedish coastal waters (Haamer 1995). Another possible influence favoring the development of Dinophysis might be the presence of relatively high concentrations of ammonia in summer (Fig. 7a). The effects of inorganic nutrients on toxin concentrations were observed by Johansson et al. (1996), and he suggested that there might be a possible increase in Dinophysis toxin production under nitrogen-sufficient and phosphorus-deficient conditions. The difficulties in collecting biological data on Dinophysis are largely caused by the the fact that species of this genus cannot be cultivated in the laboratory (Lassus et al. 1991, Delmas et al. 1992). To date, field observations are the only source for understanding Dinophysis biology. Our results showed not only that there is a clear connection between increased summer cell concentrations and mussel toxicity, but also that even slightly elevated concentrations can have a toxic effect. The persistence of particulate matter toxicity in the water column and HP toxicity of mussels which we detected well after the end of the Dinophysis bloom gives reason for concern that with the end of a Dinophysis bloom the threat of toxicity has not yet passed.

Acknowledgements. Scientists and staff of the Biologische Anstalt Helgoland are acknowledged for assistance. Special thanks go to the RV 'Aade' captain Dieter Klings and bosun Dieter Pogoda for supporting the sampling, as well as to Erik Hagmeier for helpful discussions and information. We thank Karen Wiltshire for making unpubl. data available. Victor Smetacek and Gunter-Otto Kirst are acknowledged for improving earlier versions of the manuscript. 


\section{LITERATURE CITED}

Anderson P, Hald B, Emsholm H (1996) Toxicity of Dinophysis acuminata in Danish coastal waters. In: Yasumoto $\mathrm{T}$, Oshima Y, Fukuyo Y (eds) Harmful and toxic algal blooms. Intergovernmental Oceanographic Commission of UNESCO, Paris, p 281-284

Bagu JR, Sykes BD, Craig MM, Holmes CFB (1996) A molecular basis for different interactions of marine toxins with protein phosphatase-1. J Biol Chem 272(8):5087-5097

Bauder AG, Cembella AD, Bricelj VM, Quilliam MA (2001) Uptake and fate of diarrhetic shellfish poisoning toxins from the dinoflagellate Prorocentrum lima in the bay scallop Agropecten irradians. Mar Ecol Prog Ser 213: 39-52

Bricelj VM, Shumway SE (1998) Paralytic shellfish toxins in bivalve molluscs: occurrence, transfer kinetics, and biotransformation. Rev Fish Sci 6:315-383

Budéus G (1989) Frontal variability in the German Bight. Sci Mar 53:175-185

Bundesministerium für Gesundheit (2000) Neufassung der Fischhygiene-Verordnung FNA 2125-40-54. Bundesgesetzblatt der Bundesrepublik Deutschland Teil I \#27, G5702, 23.6.2000, Bonn, p 819-845

Clausen I, Riisgard HU (1996) Growth, filtration and respiration in the mussel Mytilus edulis: no evidence for physiological regulation of the filter-pump to nutritional needs. Mar Ecol Prog Ser 141:37-45

Cranford PJ, Hill PS (1999) Seasonal variation in food utilization by the suspension-feeding bivalve molluscs Mytilus edulis and Placopecten magellanicus. Mar Ecol Prog Ser 190:223-239

Dahl E, Johannessen T (2001) Relationship between occurrence of Dinophysis species (Dinophyceae) and shellfish toxicity. Phycologia 40:223-227

Dahl E, Rogstad A, Aune T, Hormazabal V, Underdal B (1995) Toxicity of mussels to occurrence of Dinophysis species. In: Lassus P, Arzul G, Erard E, Gentien P, Marcaillou C (eds) Harmful marine algal blooms. Lavoisier, Paris, p 783-788

Dahl E, Aune T, Aase B (1996) Reddish water due to mass occurrence of Dinophysis spp. In: Yasumoto T, Oshima Y, Fukuyo Y (eds) Harmful and toxic algal blooms. Intergovernmental Oceanographic Commission of UNESCO, Paris, p 265-267

Delmas D, Herbland A, Maestrini SY (1992) Environmental conditions which lead to increase in cell density of the toxic dinoflagellates Dinophysis spp. in nutrient-rich and nutrient-poor waters of the French Atlantic coast. Mar Ecol Prog Ser 89:53-61

Dethlefsen V, von Westernhagen H (1983) Oxygen deficiency and effects on bottom fauna in the eastern German Bight 1982. Rep Mar Res 30:42-53

EU (1991) Council Directive 91/492/EEC of 15 July 1991. Official Journal of the European Union, L 268, 24/09/1991, Brussels, p 0001-0014 (http://europa.eu.int/eur-lex/)

Haamer J (1995) Presence of the phycotoxin okadaic acid in mussels (Mytilus edulis) in relation to nutrient composition in a Swedish coastal water. J Shellfish Res 14:209-216

Haamer J, Anderson PO, Lindahl O, Lange S, Li XP, Ledebo L (1990a) Geographic and seasonal variation of okadaic acid content in farmed mussels, Mytilus edulis Linnaeus, 1758, along the Swedish west coast. J Shellfish Res 9:103-108

Haamer J, Anderson PO, Lange S, Li XP, Edebo L (1990b) Effects of transplantation and reimmersion of mussels Mytilus edulis Linnaeus, 1728, on their contents of okadaic acid. J Shellfish Res 9:109-112
Hallegraeff GM (1993) A review of harmful algal blooms and their apparent global increase. Phycologia 32:79-99

Hawkins AJS, Bayne BL, Bougrier S, Heral M, Iglesias JIP, Navarro E, Smith RFM, Urrutia MB (1998) Some general relationships in comparing the feeding physiology of suspension-feeding bivalve molluscs. J Exp Mar Biol Ecol 219:87-103

Hickel W, Eickhoff E, Spindler H, Berg J, Raabe T, Müller R (1997) Auswertung von Langzeit-Untersuchungen von Nährstoffen und Phytoplankton in der Deutschen Bucht. Umweltbundesamt, Berlin, Texte 23/97

Johansson N, Granéli E, Yasumoto T, Carlsson P, Legrand C (1996) Toxin production by Dinophysis acuminata and $D$. acuta cells grown under nutrient sufficient and deficient conditions. In: Yasumoto $\mathrm{T}$, Oshima $\mathrm{Y}$, Fukuyo Y (eds) Harmful and toxic algal blooms. Intergovernmental Oceanographic Commission of UNESCO, Paris, p 277-280

Kristiansen S, Farbrot T, Naustvoll LJ (2000) Production of biogenic silica by spring diatoms. Limnol Oceanogr 45: $472-478$

Krogh P, Edler L, Graneli E, Nyman U (1985) Outbreak of diarrhetic shellfish poisoning on the west coast of Sweden. In: Anderson DM, White AW, Baden DG (eds) Toxic dinoflagellates. Elsevier, New York, p 501-503

Lassus P, Herbland A, Lebaut C (1991) Dinophysis blooms and toxic effects along the French coast. World Aquacult 22:49-54

Lindahl O, Anderson B (1996) Environmental factors regulating the occurrence of Dinophysis spp. in the Koljö Fjord, Sweden. In: Yasumoto T, Oshima Y, Fukuyo Y (eds) Harmful and toxic algal blooms. Intergovernmental Oceanographic Commission of UNESCO, Paris, p 269-272

Matsuyama Y, Uchida T, Honjo T (1997) Toxic effects of the dinoflagellate Heterocapsa circularisquama on clearance rate of the blue mussel Mytilus galloprovinciales. Mar Ecol Prog Ser 146:73-80

Nelson DM, Treguer P (1992) Role of silicon as a limiting nutrient to Antarctic diatoms: evidence from kinetic studies in the Ross Sea ice-edge zone. Mar Ecol Prog Ser 80: $255-264$

Pilet S, Houvenagel G, Lassus P, Arzul G, Erard-Le Denn E, Gentien P, Marcaillou-Le Baut C (1995) Influence of experimental toxification by DSP producing microalgae, Prorocentrum lima, on clearance rate in blue mussels Mytilus edulis. In: Lassus P, Arzul G, Erard-Le Denn E, Gentin P, Marcaillou-Le Baut C (eds) Harmful marine algal blooms. Proliferation Dálgues Marines Nuisibles. Lavoisier, Paris, p 481-486

Ramstad H, Hovgaard P, Yasumoto T, Larsen S, Aune T (2001) Monthly variations in diarrhetic toxins and yessetoxin in shellfish from coast to the inner part of the Sognfjord, Norway. Toxicon 39:1035-1043

Séchet V, Safran P, Hovgaard P, Yasumoto T (1990) Causative species of diarrhetic shellfish poisoning (DSP) in Norway. Mar Biol 105:269-274

Serres MH, Fladmark KE, Døskland SO (2000) An ultrasensitive competitive binding assay for the detection of toxins affecting protein phosphatases. Toxicon 38:347-360

Sidari L, Nichetto P, Cok S, Sosa S, Tubaro A, Honsell G, Della Loggia R (1998) Phytoplankton selection by mussels, and diarrhetic shellfish poisoning. Mar Biol 131:103-111

Suganuma M, Fujiki H, Suguri H, Yoshizawa S and 6 others (1988) Okadaic acid: an additional non-phorbol-12tetradecanoate-13-acetate-type tumor promoter. Proc Natl Acad Sci USA 85:1768-1771

Takai A, Sasaki K, Nagai H, Mieskes G, Isobe M, Isonso K, 
Yasumoto $\mathrm{T}$ (1995) Inhibition of specific binding of okadaic acid to protein phosphatase $2 \mathrm{~A}$ by microcystinLR, calyculin-A, and tautomycin: method of analysis of interactions of tight-binding ligands with target protein. Biochem J 306:657-665

Tubaro A, Florio C, Luxich E, Sosa S, Della Loggia R, Yasumoto $T$ (1996) A protein phosphatase inhibition assay for fast and sensitive assessment of okadaic acid contamination in mussels. Toxicon 34:743-752

Editorial responsibility: Otto Kinne (Editor),

Oldendorf/Luhe, Germany
Utermöhl H (1958) Zur Vervollkommnung der quantitativen Planktonmethodik. Mitt Int Ver Limnol 9:1-38

Yasumoto T, Oshima Y, Yamaguchi M (1978) Occurrence of a new type of shellfish poisoning in the Tohoku district. Bull Jpn Soc Sci Fish 44:1249-1255

Yasumoto T, Murata M, Lee JS, Torigoe K (1989) Polyether toxins produced by dinoflagellates. In: Natori S, Hashimoto $\mathrm{K}$, Ueno Y (eds) Mycotoxins and phycotoxins '88. Elsevier Science Publishers, Amsterdam, p 375-382

Submitted: May 27, 2002; Accepted: March 25, 2003

Proofs received from author(s): August 22, 2003 